\title{
Training exercise on complaints work-related musculoskeletal disorders (WMSDs) in the administration employees of BPOM lampung
}

\author{
Chika Tania \\ Fakultas Kedokteran Universitas Lampung \\ Email: chika tania821@yahoo.co.id
}

\begin{tabular}{|c|c|}
\hline ARTICLE INFO & A B STRACT \\
\hline $\begin{array}{l}\text { *) corresponding author } \\
\text { Mahasiswa, Fakultas Kedokteran, } \\
\text { Universitas Lampung } \\
\text { Jln. Hj. Agus Salim Perumahan Citra Persada } \\
2 \text { Blok B No 3-4 Tanjung Karang Barat } \\
\text { Bandar Lampung }\end{array}$ & $\begin{array}{l}\text { According to World Health Organization data, the musculoskeletal } \\
\text { incidence is estimated to reach } 60 \% \text { of all occupational diseases. Steps } \\
\text { that can be taken to overcome musculoskeletal complaints include } \\
\text { stretching exercises that can flex or relax, increase elasticity, and gain } \\
\text { comfort in the muscles. This study used the quasi-experimental method } \\
\text { with a pre and post-test control group design approach. This study used } \\
50 \text { samples divided into two groups, namely } 25 \text { respondents for the } \\
\text { control group who were not given stretching exercises and } 25 \\
\text { respondents for the treatment group who were given stretching } \\
\text { exercises for } 14 \text { working days. In each group, a musculoskeletal } \\
\text { complaint was assessed before and after treatment. Data were tested by } \\
\text { the Chi-Square test to determine the differences in each group and the } \\
\text { effect of stretching exercises on musculoskeletal complaints. The initial } \\
\text { assessment of musculoskeletal complaints before stretching exercises in } \\
\text { the treatment group was found to be mostly with moderate complaints, } \\
\text { and in the control group, the majority were with moderate complaints. } \\
\text { Data analysis with statistical tests showed that there were differences in } \\
\text { musculoskeletal complaints in the treatment group with a value of p = } \\
\text { 0.030. There is the influence of stretching exercises on complaints of } \\
\text { work-related musculoskeletal disorders (WMSDs) in the administrative } \\
\text { staff of BPOM Lampung. }\end{array}$ \\
\hline
\end{tabular}

This is an open access article under the CC-BY-SA license.

(). (1) (0)

\section{PENDAHULUAN}

Guidance on the Prevention and Management of Musculoskeletal Disorders in the Workplace dari HSENI (Health and Safety Executive for Northern Ireland) \& HSA (Health and Safety Authority) menyebutkan bahwa MSDs adalah penyebab utama kecacatan kerja di Uni Eropa. ILO mencatat anggaran bagi kecelakaan dan penyakit akibat kerja untuk muskuloskeletal sebesar $40 \%$, penyakit jantung $16 \%$, kecelakaan kerja $14 \%$, penyakit sistem saraf pusat $9 \%$ dan penyakit saluran pernafasan sebanyak $8 \%$. Dari data tersebut diketahui bahwa anggaran untuk masalah MSDs paling besar. 
Sedangkan data 3 tahun terakhir dari PT Jamsostek tentang pembayaran jaminan kecelakaan kerja (JKK) diketahui bahwa ada 83.714 kasus kecelakaan kerja yang dilaporkan pada tahun 2007, 93.823 kasus pada tahun 2008, dan 96.314 kasus pada tahun 2009.

Gangguan muskuloskeletal atau WMSDs merupakan suatu penyakit kronik atau gangguan sistem muskuloskeletal mengenai otot, saraf, tendon, ligamen, persendian, diskus invertebralis, dan pembuluh darah pada berbagai lokasi seperti leher, bahu, pergelangan tangan, pinggul, lutut, serta tumit yang memberi efek keterbatasan gerakan tubuh manusia. Faktor yang mempengaruhi terjadinya gangguan muskuloskeletal adalah faktor individu, faktor pekerjaan atau biomekanik, dan faktor psikososial. Faktor risiko yang terjadi pada pegawai kantoran adalah faktor fisik, faktor kimia, faktor biologi, faktor biomekanik terkait ergonomi, faktor individu atau karyawan, dan faktor psikososial.

Beberapa penelitian tentang peregangan otot mempunyai manfaat yang efektif untuk mengurangi keluhan WMSDs. Metode peregangan otot yang dapat dilakukan pegawai kantor sebagai langkah untuk mencegah dan mengurangi keluhan muskuloskeletal. Berdasarkan penelitian sebelumnya tentang penggunaan dan pemakaian komputer untuk bekerja pada para pekerja kantor bagian keuangan Universitas Hasanuddin Makassar didapatkan hasil 29 responden (80,6\%) dari 36 responden mengalami gangguan muskuloskeletal.

Penggunaan dan pemakaian komputer pada pekerja kantor dengan kategori duduk lebih dari 4 jam untuk bekerja memiliki risiko yang lebih tinggi menimbulkan kejadian gangguan muskuloskeletal. Menurut penelitian yang dilakukan oleh Celik dkk mengenai gangguan muskuloskeletal pada para pekerja kantor di Zonguldak, Turki didapatkan hasil dari 528 responden yang telah dilakukan pemeriksaan terdapat 55,1\% responden mengalami keluhan gangguan muskuloskeletal pada bagian punggung bawah, 53\% punggung atas, dan 52,5\% pada bagian leher. Faktor risiko pekerja kantor yang signifikan adalah duduk di kursi pada waktu yang lama tanpa istirahat, kepala yang condong $45^{\circ}$ saat bekerja, tidak stretching di kehidupan sehari-hari dan tempat kerja yang penuh tekanan.

Berdasarkan hasil penelitian pendahuluan menggunakan kuesioner pada 20 pegawai kantor administrasi BPOM Lampung yang bekerja di depan komputer didapatkan hasil bahwa, keluhan WMSDs didapatkan hasil bahwa, keluhan muskulokeletal dialami oleh semua pegawai, dengan rincian 10 orang dengan keluhan tinggi $(50 \%), 8$ orang dengan keluhan sedang $(40 \%)$, 2 orang dengan keluhan ringan (10\%).

Pegawai administrasi BPOM Lampung banyak menghabiskan waktu bekerja di depan komputer yaitu sebanyak 7 jam dalam sehari dengan posisi tubuh yang tidak ergonomi, sering melakukan pekerjaan secara berulang seperti mengetik, desain tempat kerja yang ada seperti posisi dan dimensi meja dan kursi yang tidak ergonomi serta tidak dibiasakan melakukan peregangan sebelum memulai aktivitas kerja sehingga dapat berisiko terkena keluhan muskuloskeletal seperti nyeri pada bagian leher, punggung, pinggang, dan tulang belakang. Jika hal tersebut terus terjadi makan akan berdampak terjadinya penurunan efektivitas dan efisiensi dalam kerja dan produktivitas.

\section{METODE}

Penelitian ini di lakukan di Kantor BPOM Lampung dan dilaksanakan mulai bulan April 2019. Penelitian ini merupakan penelitian quasi experimental dengan pendekatan pre dan posttest control group design. Penelitian ini dilakukan dengan cara membandingkan keluhan WMSDs antara kelompok perlakukan dan kelompok kontrol. Populasi penelitian adalah karyawan administrasi BPOM Lampung yang bekerja di depan komputer dengan keluhan WMSDs antara kelompok yang tidak diberi latihan peregangan dengan kelompok yang diberi latihan peregangan. 
Pada penelitian ini didapatkan jumlah sampel yaitu 50 orang atau 25 orang pada kelompok yang tidak diberikan latihan peregangan dan 25 orang yang diberikan latihan peregangan dengan menggunakan rumus tulang, dalam tahap proses pengobatan dan dalam masa kehamilan.

Alat yang digunakan dalam penelitian ini adalah kuesioner Nordic Body Map. Metode latihan peregangan yang dilkukan adalah latihan peregangan Kun Anta dari Dinas Kesehatan DKI Jakarta. Penelitian ini dilaksanakan selama 14 hari, dimana 0-7 hari masa preconditioning dan 8-14 hari dilakukan perlakuan latihan peregangan. Pada kelompok perlakuan diberikan latihan peregangan yang dilaksanakan pada hari tanggal 15, 17,dan 19 Juli 2019 pukul 10.00 WIB. Penilaian awal pada kelompok perlakuan dilakukan sebelum diberikan latihan peregangan dan penilaian kedua dilakukan setelah diberikan latihan peregangan. Penelitian ini mendapat persetujuan etik dari Komite Etik Penelitian Kedokteran dan Kesehatan Fakultas Kedokteran Universitas Lampung dengan nomor surat 866/UN26.18/PP.05.02.00/2019.

\section{HASIL DAN PEMBAHASAN}

Hasil penelitian yang telah dilakukan pada 50 sampel, masing-masing 25 sampel dari kantor BPOM Lampung dengan kelompok yang diberikan perlakuan serta kelompok yang tidak diberikan perlakuan. Berikut hasil distribusi frekuensi keluhan muskuloskeletal pada kelompok perlakuan.

Tabel 1

Distribusi Frekuensi Keluhan Muskuloskeletal Sebelum dan Setelah Latihan Peregangan Pada Kelompok Perlakuan

\begin{tabular}{lcccc}
\hline \multirow{2}{*}{ Keluhan } & \multicolumn{2}{c}{ X1 } & \multicolumn{1}{c}{ X2 } \\
\cline { 2 - 5 } & Frekuensi (n) & Persentase (\%) & Frekuensi (n) & Persentase (\%) \\
\hline Tidak Ada & 0 & 0 & 3 & 12 \\
Ringan & 8 & 32 & 12 & 48 \\
Sedang & 11 & 44 & 10 & 40 \\
Tinggi & 6 & 24 & 0 & 0 \\
Total & 25 & 100 & 25 & 100 \\
\hline
\end{tabular}

Berdasarkan Tabel 1 didapatkan hasil penelitian dari 25 responden pada kelompok perlakuan diketahui bahwa keluhan muskuloskeletal sebelum dilakukan latihan peregangan (pretest) sebagian besar memiliki keluhan sedang yaitu terdapat 11 responden dan 6 responden dengan keluhan tinggi. Setelah diberikan latihan peregangan Kun Anta maka didapatkan hasil responden keluhan sedang menurun menjadi 10 responden dan tidak ada yang mengalami keluhan tinggi.

Tabel 2. Distribusi Frekuensi Keluhan Muskuloskeletal pada Kelompok Kontrol

\begin{tabular}{lcccc}
\hline \multirow{2}{*}{ Keluhan } & \multicolumn{2}{c}{ X1 } & \multicolumn{2}{c}{ X2 } \\
\cline { 2 - 5 } & Frekuensi (n) & Persentase (\%) & Frekuensi (n) & Persentase (\%) \\
\hline Tidak Ada & 0 & 0 & 0 & 0 \\
Ringan & 10 & 40 & 7 & 28 \\
Sedang & 11 & 44 & 14 & 56 \\
Tinggi & 4 & 16 & 4 & 16 \\
Total & 25 & 100 & 25 & 100 \\
\hline
\end{tabular}

Berdasarkan hasil penelitian dari 25 responden yang tidak diberikan latihan peregangan (Kelompok Kontrol) didapatkan bahwa pada pengukuran kedua terdapat peningkatan keluhan muskuloskeletal 
dari pengukuran pertama yang awalnya hanya terdapat 11 responden dengan keluhan sedang dan meningkat menjadi 14 responden. Sedangkan untuk keluhan muskuloskeletal dengan keluhan tinggi tidak terjadi perubahan, yaitu tetap terdapat 4 responden dengan keluhan tinggi.

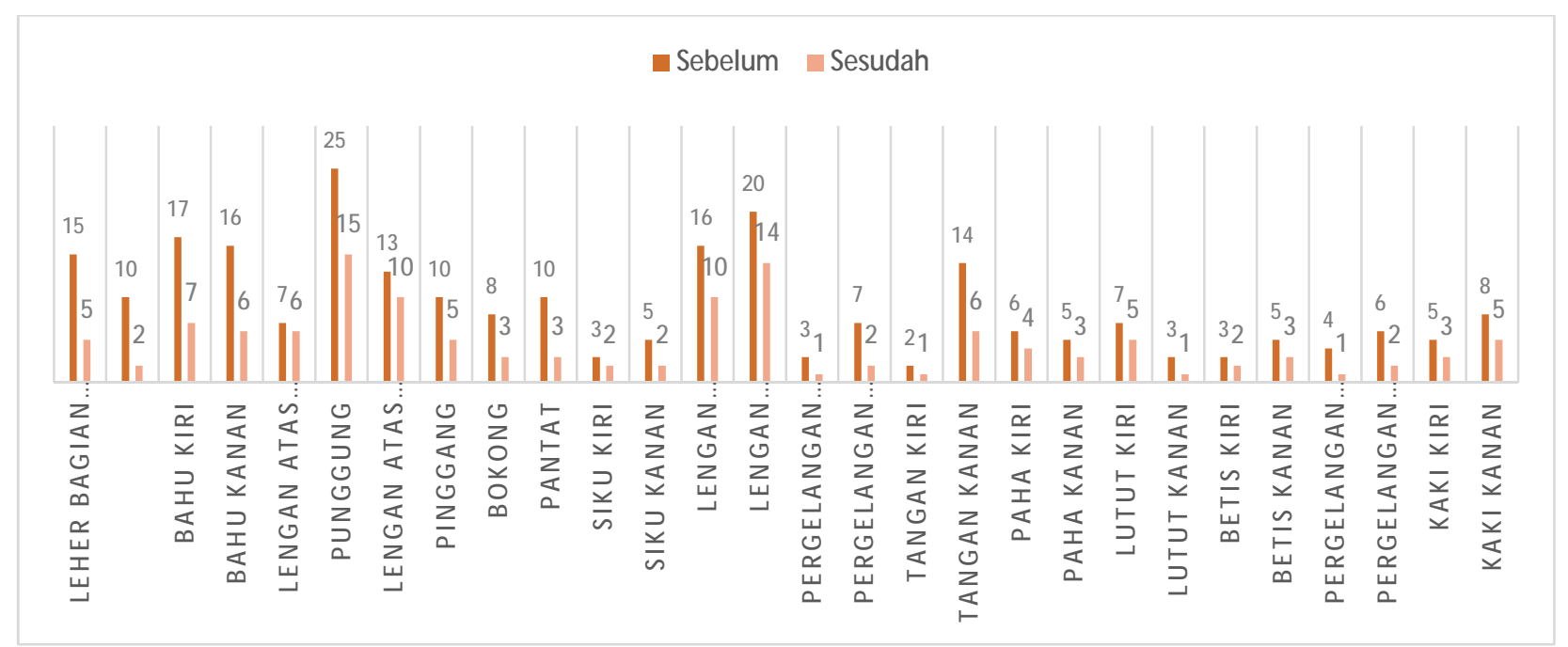

Gambar 1. Distribusi Frekuensi Lokasi Keluhan Muskuloskeletal Pada Kelompok Perlakuan

Berdasarkan Gambar 1 hasil penelitian dengan menggunakan kuesioner Nordic Body Map didapatkan gambaran keluhan muskuloskeletal sebelum dan sesudah perlakuan dengan rincian sebagai berikut:

Pada hasil penelitian berdasarkan jumlah keluhan muskuloskeletal perbagian tubuh terlihat bahwa bagian tubuh yang paling banyak dikeluhkan oleh responden yaitu pada bagian punggung sebanyak 25 orang pada saat sebelum diberikan perlakuan dan menurun menjadi 15 orang setelah dilakukan perlakuan, lengan atas kanan 15 orang pada saat sebelum diberikan perlakuan dan menurun menjadi 5 orang, bahu kiri 17 orang pada saat sebelum diberikan perlakuan dan menurun menjadi 7 orang, lengan.

Bawah kanan 20 orang pada saat sebelum diberikan perlakuan dan menurun menjadi 14 orang, leher bagian atas 15 orang pada saat sebelum diberikan perlakuan dan menurun menjadi 5 orang, lengan bawah kiri 16 orang pada saat sebelum diberikan perlakuan dan menurun menjadi 10 orang, tangan kanan 14 orang pada saat sebelum diberikan perlakuan dan menurun menjadi 5 orang.

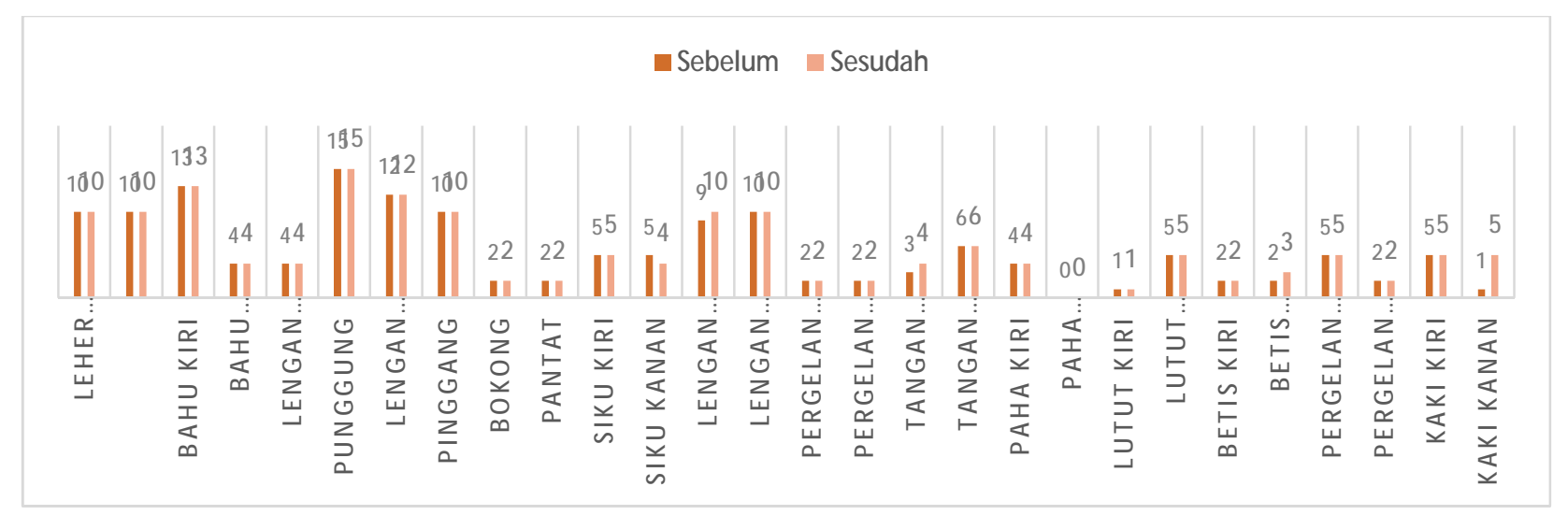

Gambar 2. Distribusi Frekuensi Lokasi Keluhan Muskuloskeletal Pada Kelompok Kontrol 
Berdasarkan pada Gambar 2 hasil penelitian berdasarkan jumlah keluhan muskuloskeletal perbagian tubuh terlihat bahwa tubuh yang paling banyak dikeluhkan oleh respoden yaitu pada baguan punggung sebanyak 15 orang pada saat sebelum penilaian dan 15 orang setelah penilaian, lengan atas kanan 12 orang, bahu kiri 13 orang pada saat sebelum penilaian dan setelah penilaian 13 orang.

Analisis perbedaan skor keluhan muskulosketal penilaian awal dan penilaian akhir pada kelompok perlakuan pada karyawan administrasi BPOM Lampung diuji dengan menggunakan uji t-test dikarenakan untuk membandingkan 2 variabel dan perbedaan rerata bermakna. Hasil analisis data dapat dilihat pada Tabel 4.

Tabel 3.

Perbedaan Skor Keluhan Muskuloskeletal Penilaian Awal dan Penilaian Akhir pada Kelompok Perlakuan

\begin{tabular}{lcc}
\hline & $\begin{array}{c}\text { Median } \\
\text { (Minimum-Maksimum) }\end{array}$ & Nilai P \\
\hline Skor Pretes Perlakuan & $58(29-90)$ & 0,000 \\
Skor Postes Perlakuan & $37(18-68)$ & \\
\hline
\end{tabular}

Berdasarkan hasil perbedaan skor pada kelompok perlakuan saat pretes dan postes didapatkan nilai $\mathrm{p}=0,000 \quad(\mathrm{p}<0,05)$. Maka pada penelitian ini didapatkan hasil terdapat perbedaan keluhan muskuloskeletal sebelum dan sesudah latihan peregangan pada kelompok kontrol, sehingga dapat disimpulkan terdapat pengaruh latihan peregangan terhadap keluhan work-related musculoskeletal $(W M S D s)$ pada karyawan kantor administrasi BPOM Lampung.

Tabel 4

Perbedaan Skor Keluhan Muskuloskeletal Penilaian Awal dan Penilaian Akhir pada Kelompok Kontrol

\begin{tabular}{lcc} 
& $\begin{array}{c}\text { Median } \\
\text { (Minimum-Maksimum) }\end{array}$ & Nilai P \\
\hline Skor Pretes Kontrol & $57(30-95)$ & 0,613 \\
Skor Postes Kontrol & $60(30-93)$ & \\
\hline
\end{tabular}

Berdasarkan Tabel 5 hasil perbedaan skor pada kelompok konyrol saat pretescdan postes didapatkan nilai $\mathrm{p}=0,0612(\mathrm{p}<0,05)$. maka pada penelitian ini didapatkan hasil tidak terdapat perbedaan keluhan muskuloskeletal sebelum dan sesudah penilaian pada kelompok kontrol, sehingga dapat disimpulkan tidak terdapat pengaruh latihan peregangan terhadap keluhan workrelated musculoskeletal (WMSDs) pada karyawan kantor administrasi BPOM Lampung.

Tabel 5

Pengaruh Latihan Peregangan Terhadap Keluhan Muskuloskeletal

\begin{tabular}{|c|c|c|c|c|c|c|c|c|c|c|c|c|}
\hline \multicolumn{13}{|c|}{ Keluhan Muskuloskeletal } \\
\hline & & \multicolumn{2}{|c|}{ Tidak } & \multicolumn{2}{|c|}{ Ringan } & \multicolumn{2}{|c|}{ Sedang } & \multicolumn{2}{|c|}{ tinggi } & \multicolumn{2}{|c|}{ Total } & \multirow[t]{2}{*}{ Nilai $p$} \\
\hline \multirow{4}{*}{$\begin{array}{l}\text { Kontrol } \\
\text { Perlakuan }\end{array}$} & & $\mathbf{n}$ & $\%$ & $\mathbf{n}$ & $\%$ & $\mathbf{n}$ & $\%$ & $\mathbf{n}$ & $\%$ & $\mathbf{n}$ & $\%$ & \\
\hline & & 0 & 0 & 7 & 28 & 14 & 24 & 4 & 16 & 25 & 100 & \multirow{3}{*}{0,030} \\
\hline & & 3 & 12 & 12 & 48 & 10 & 40 & 0 & 0 & 25 & 100 & \\
\hline & Total & 3 & 12 & 19 & 76 & 24 & 64 & 4 & 16 & 50 & 100 & \\
\hline
\end{tabular}

Berdasarkan Tabel 5 hasil penelitian pada kelompok perlakuan dan kelompok kontrol didapatkan bahwa ada perubahan keluhan muskuloskeletal pada responden, yaitu terdapat 3 orang yang mengalami perubahan dari ada keluhan menjadi tidak ada, 7 orang dengan keluhan ringan menjadi 12 orang, 14 orang dengan keluhan sedang menjadi 10 orang, dan 4 orang dengan keluhan tinggi 
menjadi tidak ada keluhan tinggi. Hasil analisis bivariat pengaruh latihan peregangan terhadap keluhan muskuloskeletal pada kelompok perlakuan didapatkan hasil nilai $p 0,030$ ( $p<0,05$ ), maka pada penelitian ini didapatkan hasil terdapat perbedaan keluhan muskuloskeletal sebelum dan sesudah latihan peregangan, sehingga dapat disimpulkan terdapat pengaruh latihan pergangan terhadap keluhan work-related musculoskeletal (WMSDs) pada karyawan kantor administrasi BPOM Lampung.

Berdasarkan hasil penelitian pada kelompok perlakuan, didapatkan bahwa sebagain besar keluhan muskuloskeletal responden sebelum diberikan latihan peregangan (pretest) yaitu terdapat 11 orang (44\%), sedangkan pada kelompok kontrol didapatkan bahwa sebagian besar responden memiliki keluhan sedang yaitu 11 orang (44\%).

Distribusi keluhan muskuloskeletal pada kelompok perlakuan pengukuran pertama yaitu sebelum diberikan perlakuan terdapat bagian tubuh yang paling banyak dikeluhkan oleh responden yaitu pada bagian punggung sebanyak 25 orang, lengan bawah kanan 20 orang, bahu kiri 17 orang, bahu kanan 16 orang, lengan bawah kiri 16 orang,leher bagian atas 15 orang, tangan kanan 14 orang .

Distribusi keluhan musculoskeletal pada kelompok perlakuan setelah penilaian kedua yaitu setelah diberikan latihan peregangan pada kelompok perlakuan didapatkan perubahan keluhan muskuloskeletal yaitu pada bagian punggung sebanyak 15 orang, lengan bawah kanan 14 orang, bahu kiri 7 orang, bahu kanan 6 orang, lengan bawah kiri 10 orang, leher bagian atas 5 orang, tangan kanan 6 orang.

Hal ini sesuai dengan penelitian yang dilakukan oleh Celik dkk yang menyatakan bahwa keluhan muskuloskeletal yang banyak ditemukan pada pekerja kantoran terutama didepan komputer yaitu pada bagian leher, lower back, dan upper back. Keluhan tersebut terjadi karena pada sebagain besar pekerja di depan komputer bekerja dengan cenderung sudut kepala condong $45^{\circ}$ sehingga dapat menimbulkan keluhan pada bagian leher, lower back, upper back, selain itu penggunaan mouse komputer yang jauh dengan keyboard juga dapat mengakibatkan efek nyeri yang signifikan pada bahu, lengan, dan upper back .

Pada kelompok perlakuan didapatkan Indeks Masa Tubuh (IMT) dimana berjumlah 12 orang normal, 7 orang obese 1, dan 6 orang kurus sedangkan pada kelompok kontrol didapatkan hasil IMT yaitu 10 orang normal, 10 orang obese 1, dan 5 orang kurus. Hasil ini juga sama dengan penelitian yang dilakukan oleh Laura Viester dkk di Britania Raya yang menunjukkan adanya hubungan Indeks Massa Tubuh terhadap gangguan muskuloskeletal. Hubungan ini terjadi karena pada orang yang memiliki Indeks Massa Tubuh berlebih memiliki kecenderungan adanya peningkatan tekanan mekanik akibat gaya gravitasi pada sistem muskuloskeletal, yang dapat berakibat pada kelelahan sampai terjadinya cedera berupa gangguan muskuloskeletal. Peningkatan tekanan mekanik ini biasanya terjadi pada bagian tubuh atau sendi-sendi yang menopang bagian tubuh manusia seperti ekstremitas bawah dan punggung.

Masa kerja merupakan rentang waktu yang telah dilewati seorang pekerja dalam menjalankan aktifitas pekerjaannya. Masa kerja pengalaman seseorang dalam suatu pekerjaan akan mempengaruhi kejadian kelelahan seseorang. Hal ini dikarenakan semakin berpengalaman seseorang dalam pekerjaanya efisiensinya dalam bekerja semakin meningkat. Pekerja yang mengalami peningkatan masa kerja akan melakukan gerakan yang berulang-ulang pada jari tangan secara terus-menerus dalam jangka waktu yang lama. masa kerja > 5 tahun dapat menyebabkan stress disekitar jaringan terowongan karpal dan akan menyebabkan sindrom terowongan karpal. Penelitian yang dilakukan didukung oleh teori Tarwaka yang menyebutkan bahwa masa kerja adalah salah satu faktor resiko keluhan muskuloskeletal yang terkait dengan semakin lamanya bekerja.. 
Semakin lama seseorang berkerja dengan meningkatnya usia maka akan terjadi degenerasi yang berupa kerusakan jaringan, pengantian jaringan menjadi jaringan parut, pengurangan cairan yang akan berakibat kepada berkurang stabilitas pada tulang dan otot. Menurut Tarwaka yang menyatakan bahwa pada umumnya keluhan otot skeletal mulai dirasakan pada usia kerja, yaitu 2565 tahun. Keluhan pertama biasanya dirasakan pada usia 35 tahun dan tingkat keluahan akan meningkat sejalan dengan bertambahnya usia. Hal ini terjadi karena pada usia setengah baya, kekuatan dan ketahanan otot mulai menurun sehingga terjadinya keluhan otot meningkat.

Berdasarkan hasil penelitian pada kelompok perlakuan didapatkan hasil bahwa sebagaian besar keluhan muskuloskeletal responden sebelum diberikan latihan peregangan (pretest) yaitu dengan keluhan ringan, setelah diberikan latihan peregangan (postest) didapatkan perubahan yaitu terdapat 3 responden menjadi tidak ada keluhan, 12 responden dari keluhan ringan, 10 responden dari keluhan sedang, dan tidak ada yang mengeluhkan keluhan tinggi.

Berdasarkan analisis uji dengan uji statistik t-test untuk mengetahui perbedaan skor antara pretest dan postest didapatkan nilai $\mathrm{p}=0,000(\mathrm{p}<0,05)$, yang berarti terdapat pengaruh latihan peregangan terhadap keluhan muskuloskeletal pada kelompok perlakuan. Hal ini sesuai dengan penelitian yang telah dilakukan oleh Levanon dkk yang menyatakan bahwa adanya perbedaan signifikasi antara responden operator komputer dengan keluhan muskuloskeletal sebelum dan sesudah intervensi dibagian bahu $\mathrm{p}=0,04$ dan leher $\mathrm{p}=0,04 \quad(\mathrm{p}<0,05)$ maka upaya untuk mengurangi keluhan muskuloskeletal pada pekerja dapat dilakukan dengan melakukan peregangan ditempat kerja. Perubahan keluhan muskuloskeletal dapat terjadi karena latihan peregangan dapat menjaga kebugaran fisik dengan menjadikan metabolisme zat-zat yang diperlukan tubuh menjadi terdistribusi dengan baik dan proses pembuangan sisa-sisa zat yang tidak diperlukan tubuh menjadi lebih efektif.

Berdasarkan hasil penelitian pada kelompok yang tidak diberikan perlakuan latihan peregangan (kelompok kontrol), didapatkan hasil bahwa pada penilian awal keluhan muskuloskeletal sebagian besar responden pada kelompok kontrol memiliki keluhan sedang. Pada penilaian kedua pada kelompok kontrol memiliki hasil peningkatan keluhan muskuloskeletal yang awalnya hanya 11 responden dengan keluhan sedang dan meningkat menjadi 14 responden. Sedangkan untuk keluhan muskuloskeletal dengan keluhan tinggi tidak terjadi perubahan, yaitu tetap terdapat 4 responden dengan keluhan tinggi.

Analisis data dengan uji $t$-test didapatkan hasil nilai $\mathrm{p}=0,613(\mathrm{p}<0,05)$ yang berarti tidak terdapat perbedaan yang signifikan antara skor keluhan muskuloskeletal sebelum dan sesudah pada kelompok yang tidak diberikan perlakuan latihan peregangan, walaupun pada distribusi frekuensi didapatkan perbedaan keluhan muskuloskelal sesudah pada kelompok kontrol, yaitu 3 responden mengalami peningkatan dari keluhan ringan dan 4 responden tetap mengalami keluhan tinggi.

Peningkatan keluhan muskuloskeletal terjadi karena otot dipaksa untuk terus berkontrasi tanpa diberikan waktu berelaksasi (peregangan) sehingga akan menekan pembuluh darah dan menyebabkan gangguan sirkulasi darah. Bekerja dengan posisi duduk yang statis dan tanpa diberikan relaksasi akan menyebabkan penekanan pada bagian otot tubuh tertentu sehingga akan berdampak terjadinya gangguan sirkulasi darah dalam tubuh dan berkurangnya pasokan oksigen $\left(\mathrm{O}_{2}\right)$ yang akan menyebabkan penimbunan asam laktat dalam tubuh dan menimbulkan nyeri pada otot. Hal inilah yang dapat menyebabkan tidak terjadi perubahan keluhan bahkan ditemukan adanya peningkatan keluhan muskuloskeletal pada kelompok kontrol.

Gerakan peregangan yang diberikan pada karyawan administrasi kantor BPOM Lampung ini berupa gerakan yang berfokus pada leher, bahu, pinggang, punggung, pergelangan tangan, lutut dan kaki yang berfungsi untuk melenturkan otot-otot dan menghilangkan kekakuan tubuh pekerja akibat duduk dalam waktu lama dan dengan posisi statis. Setiap gerakan dilakukan penahanan pada posisi 
teregang selama delapan hingga sepuluh detik untuk dapat merasakan adanya tarikan pada otot-otot. Gerakan peregangan ini dilakukan di tempat kerja dan dengan waktu sekitar 6 menit. Gerakan ini sangat sederhana, mudah dilakukan dan digunakan untuk pekerja kantor yang mengacu Dinas Kesehatan Jakarta.

Latihan fisik dapat meningkatkan kekuatan dan fleksibilitas otot, menurunkan risiko cedera pada leher, bahu, dan punggung, serta memperkuat vertebral columnLatihan fisik seperti dengan melakukan latihan peregangan akan melatih otot skeletal dan juga otot jantung, sehingga akan meningkatkan kapasitas metabolik dan fungsional dari otot skeletal, metabolisme aerob, respon perifer dan beban kerja jantung akan menurun. Peningkatan dari kekuatan otot jantung akan meningkatkan cardiac output sehingga akan meningkatkan suplai oksigen ke jaringan. Meningkatnya pasukan suplai oksigen ke jaringan dalam tubuh akan mengakibatkan sirkulasi darah menjadi lancar sehingga penimbunan asam laktat dalam tubuh tidak terjadi dan tidak menimbulkan nyeri otot.

\section{SIMPULAN DAN SARAN}

Penilaian awal keluhan muskuloskeletal pada kelompok perlakuan didapatkan 32\% lengan keluhan ringan, 44\% dengan keluhan sedang, 24\% dengan keluhan tinggi. keluhan ringan, 44\% dengan keluhan sedang, $16 \%$ dengan keluhan tinggi.

Penilaian akhir keluhan muskuloskeletal pada kelompok perlakuan didapatkan $12 \%$ dengan tidak ada keluhan, $48 \%$ dengan keluhan ringan, $40 \%$ dengan keluhan sedang. Pada kelompok kontrol didapatkan $28 \%$ dengan keluhan ringan, 56\% dengan keluhan sedang, dan $16 \%$ dengan keluhan tinggi.

Terdapat pengaruh latihan peregangan terhadap keluhan work-related musculoskeletal disorders (WMSDs) pada karyawan administrasi BPOM Lampung.

\section{DAFTAR PUSTAKA}

American College of Sports Medicine (ACSM).2013. ACSM's Metabolic Calculations Handbooks. Lippincott Williams and Wilkins. Baltimore.

Ariyanto J. 2013. Faktor-faktor yang berhubungan dengan kejadian musculoskeletal disorders pada aktivitas manual handling oleh karyawan mail processing center Makasar. Universitas Hasanudin [diunduh 30 November 2018]. Tersedia dari: http:/repository.unhas.ac.id/bitstream/handle/123456789/4458.

Beswick AD, Rees K, Dieppe P, Ayis S, Gooberman-Hill R, Horwood J, dkk. 2008. Complex interventions to improve physical function and maintain independent living in elderly people; a systematic review and meta-analysis. The Lancet. 371:725-35.

Celik S, Celik K, Dirimese E, Tasdemir N, Arik T, Buyakkara I. 2018. Determination of pain in musculoskeletal system reported by office workers and the pain risk factors. International Journal of Occupational Medicine and Environmental Health. 31(1):9-111.

Guyton AC, Hall JE. 2008. Buku Ajar Fisiologi Kedokteran. Edisi 11. Jakarta: EGC.

ILO.2003. Keselamatan dan Kesehatan Kerja. Dalam Tarwaka. 2008. Keselamatan dan Kesehatan Kerja. Surakarta. Harapan Press.

Kurniawidjaja, L. Meily.2010. Teori dan Aplikasi Kesehatan Kerja. Jakarta.UIPress. 
Levanon Y, Gefen A, Lerman Y, Givon U, Ratzon NZ. 2012. Reducing musculoskeletal disorders among computer operators: Comparison between ergonomics interventions at the workplace. Ergonomic. 55(12): 1571-85.

Saputra AM, Furqaan MF, Saleh M. 2012. Factors related with musculoskeletal disorders on hasanuddin university Makassar financial department computer operator. Jurnal Administrasi Publik. 1(2):131-9.

Sudoyo AW, Setiyohadi B, Alwi I, Simadibrata M, Setiati S. 2009. Buku Ajar Ilmu Penyakit Dalam. Jilid III. Edisi V. FKUI. Jakarta: Interna Publishing.

Suharjana F. 2013. Perbedaan pengaruh hasil latihan peregangan statis dan dinamis. Jurnal Pendidikan Jasmani Indonesia. 9(1):38-46.

Tarwaka. 2014. Keselamatan dan Kesehatan Kerja: Manajemen dan Implementasi K3 di Tempat Kerja. Harapan Press. Surakarta.

Viester, L.;Verhagen E, ALM.; Hengel, K, L, M.; Koppes, L, L, J.; Van der Beek, A, J.; Bongers, P, M. 2013. The relation between body mass index and musculoskeletal symptoms in the working population. BMC Musculoskeletal Disorders, Vol. 14:238. 
Wellness and Healthy Magazine, 2(1), February 2020, - 104

Chika Tania 